\title{
Glucose Utilization of Cardiac and Skeletal Muscle Homogenates from Fetal and Adult Rhesus Monkeys
}

\author{
Glarissa H. Beatty ${ }^{[46]}$, Martha K. Young, David Dwyer, and Rose Mary Bocek \\ Departments of Biochemistry, Oregon Regional Primate Research Center, Beaverton, Oregon, and University of Oregon Medical \\ School, Portland, Oregon, USA
}

\section{Extract}

The oxygen consumptions and $\mathrm{CO}_{2}$ productions were similar for the homogenates of adult and 113-day fetal muscle from rhesus monkeys but higher in the 155-day fetal series (Table I). The percentages of total $\mathrm{CO}_{2}$ and the micromoles of $\mathrm{CO}_{2}$ arising from glucose plus glycogen (carbohydrate) were the same in homogenates of fetal and adult skeletal muscle. No difference was observed between the metabolism of homogenates of adult and neonatal muscle.

In homogenates of cardiac muscle, the oxygen consumption and $\mathrm{CO}_{2}$ production in fetal muscle were higher at 113 days than in adult muscle; by 155 days, values in the fetal and adult muscle were similar (Table I). The percentage of total $\mathrm{CO}_{2}$ arising from carbohydrate and the micromoles of $\mathrm{CO}_{2}$ produced from the oxidation of carbohydrate were higher in both fetal series than in the adult. The oxygen consumption, $\mathrm{CO}_{2}$ production, and micromoles of $\mathrm{CO}_{2}$ arising from carbohydrate per gram protein per 30 min were two- to sevenfold higher in cardiac than in skeletal muscle, the greatest difference occurring in the 113-day fetal series. However, the percentages of total $\mathrm{CO}_{2}$ arising from carbohydrate were remarkably similar; the only difference was seen in the adult series where skeletal muscle was relatively more dependent on carbohydrate as a substrate than cardiac muscle. All these parameters were also measured in homogenates of cardiac muscle from neonates, and no difference in metablism was observed between the neonatal and adult series.

In the fetal homogenates from both types of muscle, a major portion, 65 to $73 \%$, of the total $\mathrm{CO}_{2}$ produced originated from a source or sources other than glucose and glycogen. Thus, both skeletal and cardiac homogenates of fetal, neonatal, and adult muscle are potentially able to obtain a large portion of their energy from the oxidation of substrates other than glucose and glycogen.

\section{Speculation}

In vitro experiments from our laboratory demonstrate that $65 \%$ or more of the total $\mathrm{CO}_{2}$ produced by skeletal and cardiac muscle homogenates originated from the oxidation of substrates other than glucose and glycogen in the fetal as well as in the adult series; the data from broken cell preparations (homogenate) and previous data from intact cell preparations (muscle fiber groups) are similar. The possibility that other tissues and organs of the fetus utilize noncarbohydrates as an energy 
source should be investigated. Tsoulos et al. have reported that fetal lambs obtain a maximum of $50 \%$ of their metabolic requirements from glucose utilization under presumably normal conditions.

\section{Introduction}

The comment has frequently been made that the mammalian fetus develops in a chronically hypoxic environment [38]. However, how the growing fetus with a low oxygen consumption can perform synthetic processes at a rapid rate is difficult to understand. Synthetic processes are relatively expensive in terms of the amounts of high energy compounds such as adenosine triphosphate (ATP) that are required, and adequate oxygenation is necessary for the efficient production of these energy stores. Work in our laboratory $[6,7]$ has demonstrated that skeletal muscle fiber groups from fetal and neonatal rhesus monkeys (Macaca mulatta) have a higher oxygen consumption and $\mathrm{CO}_{2}$ production, expressed on the basis of noncollagenous protein nitrogen, than adult muscle fiber groups; glucose uptake of rapidly growing skeletal muscle at 90 and 125 days fetal age ( 54 and $75 \%$ of term) was higher than that of the adult. Clark [14] has reported that the glucose uptake of perfused rat hearts was higher at 15 days fetal age than at term (22 days fetal age); however, no adult values were obtained. Rodis and Vahouny [31] reported that the glucose uptake of perfused rat hearts at 3 weeks after birth was higher than in the adult series; oxygen consumptions were not measured by either Clark or Rodis and Vahouny.

Data on intact cell preparations may be influenced by the differences between fetal and adult muscle in transport and permeability across the cell membrane. The rate-limiting step in glucose metabolism by adult muscle, for example, is transport across the cell membrane. Our laboratory has demonstrated an increased uptake of $\alpha$ aminoisobutyric acid by muscle fiber groups of fetal monkeys over that of adult monkeys. Unfortunately, published data on broken cell preparations of fetal and neonatal muscle are sparse. Kiessling $[23,24]$ found that $\mathrm{QO}_{2}$ of homogenates and mitochondria from voluntary skeletal muscle of neonatal rats was lower than that from adults. Jolley, Cheldelin, and Newburgh [22] found that the production of ${ }^{14} \mathrm{CO}_{2}$ from labeled glucose was threeto fourfold higher in adult heart homogenates than in fetal heart homogenates of rats, whereas Wittels and Bressler [41] reported that heart homogenates from neonatal rats oxidized more glucose $-{ }^{14} \mathrm{C}$ to ${ }^{14} \mathrm{CO}_{2}$ than those from adults; no values were reported for total oxygen consumption in these two papers. Fatty acid utilization by the neonatal heart has been reported to be both present $[31,41]$ and absent [11]. In view of these conflicting results, we decided to compare the metabolism of heart and skeletal muscles from fetal, neonatal, and adult monkeys using an homogenate preparation. In the experiments reported here, we measured oxygen consumption and total $\mathrm{CO}_{2}$ production as well as glucose- ${ }^{14} \mathrm{C}$ utilization to allow comparison of the relative amounts of glucose oxidized by homogenates from rapidly growing and adult monkeys in terms of the overall metabolic rate. The experiments were designed to provide a sufficient amount of cofactors to insure maximum utilization of glucose.

\section{Methods}

Female rhesus monkeys, 102- to 162-day pregnant, were anesthetized with $1 \%$ or less of fluothane (2-bromo-2chloro-1:1:1-trifluoroethane) in a mixture of $75 \%$ oxygen and $25 \%$ nitrous oxide, and the fetuses were obtained by cesarian section. The average gestational period for rhesus monkeys in our colony is 166 days. Neonatal and adult monkeys were anesthetized with Sernylan (1-(phenylcyclohexyl)piperidine $\mathrm{HCl}), \quad 1.0$ $\mathrm{mg} / \mathrm{kg}$ intramuscularly, or Ketaject (DL-2-(o-chlorophenyl)-2-(methamino)cyclohexanone hydrochloride), 9 $\mathrm{mg} / \mathrm{kg}$ intramuscularly. Skeletal muscle was obtained from the upper part of the hind limbs of fetal and neonatal monkeys and from the sartorius muscle of adults. Excised skeletal muscles were rapidly cut into small strips and placed in iced $150 \mathrm{~mm} \mathrm{KCl}$. For experiments on cardiac muscle, the ventricles were cut into longitudinal strips and placed in iced $150 \mathrm{~mm} \mathrm{KCl}$. The tissues were dissected free of fibrous and adipose tissue and finely minced with scissors in modified Chappell-Perry medium (100 mм KCl; $100 \mathrm{~mm} N$-tris(hydroxymethyl)methyl-2-aminoethanesulfonic acid [TES] buffer, $\mathrm{pH}$ 7.4; $1 \mathrm{~mm}$ ATP; $5 \mathrm{~mm} \mathrm{MgSO} 4$; and $1 \mathrm{~mm}$ ethylenediaminetetraacetate [EDTA]) at 0 to $4^{\circ}[20,21]$. The muscle mince was homogenized in modified ChappellPerry medium $(17 \%, \mathrm{w} / \mathrm{v})$ with a $\mathrm{CO}_{2}$-cooled mechanical cell homogenizer $[28,42]$, run for $30 \mathrm{sec}$ at $4000 \mathrm{cpm}$ with a bead to tissue ratio of $6: 1(\mathrm{w} / \mathrm{w})$. In the 113-day fetal heart homogenate the muscle mince was $10 \%$, $\mathrm{w} / \mathrm{v}$. The resultant homogenate was centrifuged at $500 \times$ $g$ for 10 min $\left(4^{\circ}\right)$. Observations of the supernatant with 
the electron microscope showed many intact mitochondria with an occasional collagen fiber. Two milliliters of the supernatant were added to $2 \mathrm{ml}$ incubation medium in Warburg flasks (final concentration in the flask, $70 \mathrm{~mm} \mathrm{KCl} ; 1 \mathrm{~mm} \mathrm{ATP;} 1 \mathrm{~mm} \mathrm{ADP} ; 40 \mu \mathrm{m}$ coenzyme A [CoA]; 0.5 mм EDTA; 5 mм $\mathrm{MgSO}_{4} ; 8$ mм $\mathrm{K}_{2} \mathrm{HPO}_{4}$; $0.2 \mathrm{~mm}$ triphosphopyridine nucleotide [TPN]; $0.5 \mathrm{~mm}$ diphosphopyridine nucleotide [DPN]; $60 \mathrm{~mm}$ sucrose; $11 \mathrm{~mm}$ glucose; $100 \mathrm{~mm}$ TES buffer, $\mathrm{pH} 7.4,37^{\circ}$; and $0.5 \%$ albumin). Albumin was purified by treatment with charcoal, dialyzed for $36 \mathrm{hr}$ in boiled visking tubing against running distilled water at $4^{\circ}$, lyophilized, and stored at $4^{\circ}$ [13]. The medium also contained $0.2 \mu \mathrm{Ci}$ glucose- $U-{ }^{14} \mathrm{C} / \mathrm{ml}$. Four-tenths milliliter $9.5 \mathrm{~N} \mathrm{NaOH}$ was added to a sidearm, and the flasks were incubated $30 \mathrm{~min}$ at $37^{\circ}$. At zero time, $0.1 \mathrm{ml} 18 \mathrm{~N} \mathrm{H}_{2} \mathrm{SO}_{4}$ was added with a syringe and needle to the medium of control flasks through a vial closure on a sidearm, and the flasks were shaken for $40 \mathrm{~min}$ to allow $\mathrm{CO}_{2}$ absorption into the alkali.

The oxygen consumption of the homogenate was measured manometrically. The flasks reached equilibrium in $10 \mathrm{~min}$ or less, and the 30 -min oxygen uptake was calculated by extrapolation based on the assumption that the uptake was linear for the first $30 \mathrm{~min}$. Incubation was terminated as before by the addition of $0.1 \mathrm{ml} 18 \mathrm{~N} \mathrm{H}_{2} \mathrm{SO}_{4}$, and the flask was shaken for $40 \mathrm{~min}$ to allow $\mathrm{CO}_{2}$ absorption by the $\mathrm{NaOH}$. The total $\mathrm{CO}_{2}$ was determined with an automatic analyzer [43] on an aliquot of the $\mathrm{NaOH}$ collected under nitrogen. To calculate $\mathrm{CO}_{2}$ production, we subtracted the values for $\mathrm{CO}_{2}$ in the medium plus homogenate at zero time from the values obtained at the end of incubation. Glucose and lactate analyses were done as previously described [9]. Lactate productions were calculated from the concentration in the medium after $30 \mathrm{~min}$ of incubation minus the concentration in the medium at zero time. The protein content of the homogenate was determined by Lowry's method [25], and all the data were reported in terms of protein content.

The radioactivity of the medium was measured by the addition of a 25- $\mu \mathrm{l}$ aliquot to $10 \mathrm{ml}$ omnifluor scintillation fluid (toluene-ethanol). Radioactivity of the $\mathrm{CO}_{2}$ and lactate was determined with a low background counter [44] as previously described [9]. The production of ${ }^{14} \mathrm{CO}_{2}$ and lactate- ${ }^{14} \mathrm{C}$ in the absence of metabolizing tissue was measured in the control flasks at zero time. All results were corrected to disintegrations per minute by means of internal or external standards.

The percentage of lactate arising from substrate glucose ${ }^{14} \mathrm{C}$ was calculated from the specific activity of the lactate (disintegrations per minute per millimole carbon) divided by the specific activity of the substrate glucose (disintegrations per minute per millimole carbon) times 100. The remainder of the lactate (unlabeled) was assumed to arise from glycogen. The dilution of lactate- ${ }^{14} \mathrm{C}$ by unlabeled lactate from glycogen is a sensitive method for demonstrating glycogenolysis in vitro. We realize that calculating glycogen breakdown by this method yields minimum values. He assume that most of the unlabeled lactate arises from glycogen although a minimum amount could be formed from deaminating amino acids or converting malate or oxalacetate to lactate; some labeled glucosyl units from glycogen could also be metabolized to lactate. The percentage of total $\mathrm{CO}_{2}$ arising from labeled glucose was calculated from the specific activity of the $\mathrm{CO}_{2}$ (disintegrations per minute per millimole carbon) divided by the specific activity of the substrate glucose ${ }^{14} \mathrm{C}$ (disintegrations per minute per millimole carbon) times 100. Since the amount of lactate arising from glycogen can be estimated, the percentage of total $\mathrm{CO}_{2}$ arising from carbohydrate (glucose plus glycogen) can also be calculated. The calculation of percentage of $\mathrm{CO}_{2}$ from glucose and glycogen assumes that these are the only carbohydrate sources available. However, other glycolytic intermediates are present, although in small amounts as compared with the levels of glucose and glycogen, and these intermediates can be utilized by fetal tissues [37]. Carbon dioxide derived from these endogenous substrates could have diluted the specific activity of the ${ }^{14} \mathrm{CO}_{2}$.

Differences in means were not considered significant unless the $P$ value was $<0.05$.

\section{Results}

The oxygen consumptions and $\mathrm{CO}_{2}$ productions were similar for the homogenates of adult and 113-day fetal muscle but higher in the 155-day fetal series (Table I). In general, these results agree with previous data on muscle fiber groups (intact cell preparations) in which oxygen consumption and $\mathrm{CO}_{2}$ production of fetal muscle were usually as high as or higher than those of adult muscle although the gestational ages at which the maximum values occurred were not necessarily identical in homogenate and intact cell preparations $[6,7]$. The percentages of total $\mathrm{CO}_{2}$ and the micromoles of $\mathrm{CO}_{2}$ arising from glucose plus glycogen (carbohydrate) were the same in homogenates of fetal and adult skeletal muscle (Table I). The production of $\mathrm{CO}_{2}$ from glucose by rhesus skeletal muscle reflects mainly citric acid cycle activity, since the utilization of glucose via the pentose 
Table $I$. Metabolism of homogenates of skeletal and cardiac muscle from fetal, neonatal, and adult rhesus monkeys ${ }^{1}$

\begin{tabular}{|c|c|c|c|c|c|c|c|}
\hline & \multirow{2}{*}{ Adult 2} & \multicolumn{2}{|c|}{ Neonatal ${ }^{3}$} & \multicolumn{4}{|c|}{ Fetal ${ }^{4}$} \\
\hline & & 3 days & $\begin{array}{l}P v s \\
\text { adult }\end{array}$ & 155 days & $\begin{array}{l}P \text { vs } \\
\text { adult }\end{array}$ & 113 days & $\begin{array}{l}P \text { vs } \\
\text { adult }\end{array}$ \\
\hline & & & & eletal muscle & & & \\
\hline \multicolumn{8}{|l|}{$\mu$ moles $/ g$ protein $/ 30 \mathrm{~min}$} \\
\hline $\mathrm{O}_{2}$ consumption ${ }^{5}$ & $157 \pm 9$ & $162 \pm 17$ & NS & $232 \pm 27$ & $<0.05$ & $170 \pm 27$ & NS \\
\hline $\mathrm{CO}_{2}$ production & $159 \pm 10$ & $204 \pm 25$ & NS & $230 \pm 20$ & $<0.05$ & $149 \pm 18$ & NS \\
\hline $\mathrm{CO}_{2}\left(\mathrm{dpm} \times 10^{3} / \mu\right.$ mole $)$ & $2.2 \pm 0.2$ & $1.8 \pm 0.3$ & NS & $1.5 \pm 0.1$ & $<0.05$ & $1.6 \pm 0.1$ & $<0.05$ \\
\hline$\%$ total $\mathrm{CO}_{2}$ from glucose $\mathrm{-}^{-14} \mathrm{C}$ & $31 \pm 4$ & $25 \pm 3$ & NS & $21 \pm 3$ & $<0.05$ & $23 \pm 2$ & $<0.05$ \\
\hline $\begin{array}{l}\% \text { total } \mathrm{CO}_{2} \text { from glucose }-{ }^{-14} \mathrm{C}+ \\
\text { glycogen }\end{array}$ & $34 \pm 3$ & $27 \pm 3$ & NS & $27 \pm 4$ & NS & $30 \pm 4$ & NS \\
\hline $\begin{array}{l}\mu \text { moles } \mathrm{CO}_{2} \text { from carbohydrate } / \mathrm{g} \\
\text { protein } / 30 \mathrm{~min}\end{array}$ & $54 \pm 4$ & $55 \pm 5$ & NS & $62 \pm 5$ & NS & $45 \pm 4$ & NS \\
\hline \multicolumn{8}{|l|}{$\mu$ moles $/ g$ protein $/ 30 \mathrm{~min}$} \\
\hline $\mathrm{O}_{2}$ consumption 5 & $487 \pm 20^{7}$ & $451 \pm 26^{7}$ & NS & $501 \pm 50^{7}$ & NS & $800 \pm 13^{7}$ & $<0.01$ \\
\hline $\mathrm{CO}_{2}$ production & $570 \pm 31^{7}$ & $580 \pm 25^{7}$ & NS & $644 \pm 40^{7}$ & NS & $848 \pm 12^{7}$ & $<0.01$ \\
\hline \multicolumn{8}{|l|}{ Specific activity } \\
\hline Lactate $\left(\mathrm{dpm} \times 10^{4} / \mu\right.$ mole $)$ & $2.1 \pm 0.2$ & $2.1 \pm 0.3$ & NS & $1.9 \pm 0.2$ & NS & $1.9 \pm 0.2$ & NS \\
\hline $\mathrm{CO}_{2}\left(\mathrm{dpm} \times 10^{3} / \mu\right.$ mole $)$ & $1.5 \pm 0.1$ & $1.5 \pm 0.2$ & NS & $1.8 \pm 0.2$ & NS & $2.2 \pm 0.2$ & $<0.02$ \\
\hline$\%$ total $\mathrm{CO}_{2}$ from glucose $-{ }^{14} \mathrm{C}$ & $21 \pm 2^{7}$ & $22 \pm 1$ & NS & $26 \pm 3$ & NS & $32 \pm 2$ & $<0.01$ \\
\hline $\begin{array}{l}\% \text { total } \mathrm{CO}_{2} \text { from glucose }{ }^{-14} \mathrm{C}+ \\
\text { glycogen }\end{array}$ & $21 \pm 2^{7}$ & $22 \pm 1$ & NS & $29 \pm 2$ & $<0.05$ & $35 \pm 2$ & $<0.01$ \\
\hline $\begin{array}{l}\mu \text { moles } \mathrm{CO}_{2} \text { from carbohydrate } / \mathrm{g} \\
\text { protein } / 30 \mathrm{~min}\end{array}$ & $120 \pm 2^{7}$ & $128 \pm 15^{7}$ & NS & $188 \pm 12^{7}$ & $<0.01$ & $297 \pm 20^{7}$ & $<0.01$ \\
\hline $\begin{array}{l}\text { Protein concentration, }{ }^{6} \mathrm{mg} / \mathrm{ml} \text { ho- } \\
\text { mogenate }\end{array}$ & $6.0 \pm 0.5$ & $6.0,6.3$ & & $4.9 \pm 0.5$ & NS & $2.7 \pm 0.1$ & $<0.01$ \\
\hline
\end{tabular}

${ }^{1}$ Values are means \pm SEM, duplicate flasks on each observation. Homogenates were incubated for 30 min at $37^{\circ}$ in TES buffered medium, $\mathrm{pH} 7.4$, plus $0.21 \mu \mathrm{Ci}$ glucose-U $-{ }^{14} \mathrm{C}$ per $\mathrm{ml}$ (specific activity $4.2 \times 10^{4} \mathrm{dpm} / \mu \mathrm{mole}$ ). NS: Not significant.

${ }^{2} \mathrm{Six}$ animals.

3 Two animals.

${ }^{4}$ Five animals.

5 Estimated from the final $20 \mathrm{~min}$ of incubation assuming linearity of oxygen consumption.

${ }^{6}$ Determined by Lowry's method [25].

${ }^{7} P$ skeletal os cardiac $<0.01$.

cycle is insignificant [4]. All the parameters we have discussed were also measured in homogenates of muscle from neonates; no difference was observed between the metabolism of homogenates of adult and neonatal muscle.

In homogenates of cardiac muscle, the oxygen consumption and $\mathrm{CO}_{2}$ production in fetal muscle were higher at 113 days than in adult muscle; by 155 days, values in the fetal and adult muscle were similar (Table I). The percentage of total $\mathrm{CO}_{2}$ arising from carbohydrate and the micromoles of $\mathrm{CO}_{2}$ produced from the oxidation of carbohydrate were higher in both fetal series than in the adult. All these parameters were also measured in homogenates of cardiac muscle from neonates, and no difference in metabolism was observed between the neonatal and adult series (Table I).

The oxygen consumption, $\mathrm{CO}_{2}$ production, and micromoles of $\mathrm{CO}_{2}$ arising from carbohydrate per gram protein per $30 \mathrm{~min}$ were two- to sevenfold higher in cardiac than in skeletal muscle, the greatest difference occurring in the 113-day fetal series. However, the percentages of total $\mathrm{CO}_{2}$ arising from carbohydrate were remarkably similar; the only difference was seen in the adult series where skeletal muscle was relatively more dependent on carbohydrate as a substrate than cardiac muscle (Table I). This difference between skeletal and cardiac 
muscle in the percentage of $\mathrm{CO}_{2}$ from carbohydrate disappeared in the fetal series because the fetal myocardial homogenate was more dependent than the adult on carbohydrate as demonstrated by the higher percentage of total $\mathrm{CO}_{2}$ arising from carbohydrate in the fetal series.

The protein concentrations of both types of muscle

Table II. Effect of protein concentration on the oxygen consumption and $\mathrm{CO}_{2}$ production of cardiac muscle homogenates from adult rhesus monkeys ${ }^{1}$

\begin{tabular}{|c|c|c|c|}
\hline & Control ${ }^{2}$ & Diluted $1: 1^{3}$ & $p$ \\
\hline $\begin{array}{l}\mathrm{QO}_{2}^{4}, \mu \text { moles/g pro- } \\
\text { tein } / 30 \text { min }\end{array}$ & $501 \pm 21$ & $547 \pm 27$ & NS \\
\hline $\begin{array}{l}\mathrm{CO}_{2}, \mu \text { moles } / g \text { pro- } \\
\text { tein } / 30 \mathrm{~min}\end{array}$ & $621 \pm 30$ 理 & $596 \pm 21$ & NS \\
\hline
\end{tabular}

1 Values are means \pm SEM, duplicate flasks, three monkeys. Statistical analysis on the basis of paired observations. Conditions of experiment as in Table I.

2 Protein concentration $6 \mathrm{mg} / \mathrm{ml}$.

${ }^{3}$ Protein concentration $3 \mathrm{mg} / \mathrm{ml}$.

${ }^{4}$ Estimated from the final $20 \mathrm{~min}$ of incubation.

Table III. Oxygen uptake of homogenates of skeletal and myocardial muscle from adult rhesus monkeys ${ }^{1}$

\begin{tabular}{lcc}
\hline & \multicolumn{2}{c}{ Skeletal muscle } \\
\cline { 2 - 3 } & $10-20 \mathrm{~min}$ & $20-30 \mathrm{~min}$ \\
\hline $\mathrm{QO}_{2}, \mu$ moles/g protein/30 min & $60 \pm 7$ & $58 \pm 6$ \\
\hline & \multicolumn{2}{c}{ Cardiac muscle } \\
\hline $\mathrm{QO}_{2}, \mu$ moles/g protein/30 min & $175 \pm 20$ & $161 \pm 18$ \\
\hline
\end{tabular}

1 Values are means $\pm \mathrm{sEm}$, five monkeys (duplicate flasks). Homogenates were incubated for $30 \mathrm{~min}$ at $37^{\circ}$ in TES buffered medium, $\mathrm{pH} 7.4$, plus $0.2 \mu \mathrm{Ci}$ glucose- $\mathrm{U}-{ }^{14} \mathrm{C}$ and $11.1 \mu$ moles glucose per ml. Warburg flasks were equilibrated for $10 \mathrm{~min}$ and manometer readings were obtained for the second and third 10 -min periods. homogenate preparations averaged between 6 and 8 $\mathrm{mg} / \mathrm{ml}$ except for the 113-day fetal heart preparation. Because of the small size of the heart at this age, the protein concentration was lower in this series. However, diluting a cardiac homogenate $1: 1$ with homogenizing medium had no effect on either $\mathrm{QO}_{2}$ or $\mathrm{CO}_{2}$ production in this experiment (Table II).

Respiratory quotient values were not calculated because the figure for oxygen consumption was estimated for the last $20 \mathrm{~min}$ of incubation on the assumption that the metabolic rate was uniform over the entire 30 -min experimental period. Manometer readings could not be obtained earlier than $10 \mathrm{~min}$ since this period was needed for temperature equilibration; however, the values for oxygen consumption of both skeletal and cardiac muscle were constant over the second and third 10-min incubation periods (Table III). When we collected 10 min samples of $\mathrm{CO}_{2}$, the $\mathrm{CO}_{2}$ production was significantly higher during the first $10 \mathrm{~min}$ of incubation (Table IV). We conclude, then, that the $\mathrm{QO}_{2}$ value was also higher during this period. This would mean that the "estimated" $\mathrm{QO}_{2}$ values were low and the correct values for RQ are lower than those indicated by the data presented. Lactate production measured over $10-\mathrm{min}$ increments was also constant for as long as 50 min incubation. In the first $10-$ min period lactate production was $66 \pm 8 \mu$ moles $/ g$ protein, and there was no significant change in production during any of the subsequent periods $(P>0.10)$.

\section{Discussion}

The fact that during the last half of gestation homogenates of both skeletal and cardiac muscle from fetal rhesus monkeys utilize as much as or more oxygen than those of adult muscle agrees with previous results in our laboratory with muscle fiber groups $[6,7]$ but not with

Table IV. Oxygen consumption and $\mathrm{CO}_{2}$ production of skeletal muscle homogenates from rats ${ }^{\mathrm{L}}$

\begin{tabular}{|c|c|c|c|c|c|}
\hline & \multicolumn{5}{|c|}{ Time } \\
\hline & $\stackrel{A}{0-10 \mathrm{~min}}$ & $\stackrel{B}{B}$ & $\begin{array}{c}C \\
20-30 \mathrm{~min}\end{array}$ & $\begin{array}{c}\mathrm{D} \\
30-40 \text { min }\end{array}$ & $\underset{40-50 \text { min }}{\mathrm{E}}$ \\
\hline $\begin{array}{l}\mathrm{QO}_{2}{ }^{2} \\
\underset{\mu \text { moles } / g \text { protein }}{P^{3}}\end{array}$ & & $80 \pm 2$ & $\begin{array}{c}70 \pm 4 \\
<0.05\end{array}$ & $\begin{array}{c}65 \pm 4 \\
\text { NS }\end{array}$ & $\begin{array}{c}60 \pm 6 \\
\text { NS }\end{array}$ \\
\hline $\begin{array}{l}\mathrm{CO}_{2} \text { production } \\
\mu \text { moles } / \mathrm{g} \text { protein } \\
P^{3}\end{array}$ & $113.0 \pm 21$ & $\begin{array}{l}74 \pm 9 \\
<0.025\end{array}$ & $\begin{array}{c}76 \pm 9 \\
\mathrm{NS}\end{array}$ & $\begin{array}{c}76 \pm 10 \\
\text { NS }\end{array}$ & $\begin{array}{c}73 \pm 16 \\
\text { NS }\end{array}$ \\
\hline
\end{tabular}

1 Values are means $\pm \mathrm{sem}$, five rats in series $A, B$, and $C$, three rats in series $D$ and $E$ (duplicate flasks). Homogenates were incubated at $37^{\circ}$ in TES buffered medium, pH 7.4 , plus $11.1 \mu$ moles glucose per ml.

${ }^{2}$ Flasks were equilibrated for $10 \mathrm{~min}$, and manometer readings were obtained at 10 -min periods thereafter.

${ }^{3}$ Each period of time is compared with the preceding period. 
results in the literature $[23,24]$. The lower $\mathrm{QO}_{2}$ values reported by others for homogenates of rapidly growing muscle than for those of adult muscle may have been due to damage to the more fragile rapidly growing tissue during preparation. In our experience, homogenates prepared with the Bronwill $\mathrm{CO}_{2}$-cooled apparatus are biochemically superior to those prepared by more conventional methods such as the conical glass-glass homogenizer. Thus this new homogenizing technique may account for the higher metabolic rate of our fetal preparation.

Not all investigators agree with the theory that the mammalian fetus, even under normal intrauterine conditions, develops with a deficient oxygen supply. Räihä and Mäenpää [30] determined the lactate to pyruvate and ATP to ADP ratios of fetal rat livers and found no evidence of inadequate oxygenation in this tissue. Misrahy et al. [26], who measured oxygen availability in fetal and adult guinea pig brain by a polarographic technique, reported that the values were similar in the two series if 2 to $3 \mathrm{hr}$ were allowed for recovery from surgery.

The overall $\mathrm{O}_{2}$ consumption of the fetus is difficult to assess. Assali et al. [3] believe that most of the estimates of the oxygen supply to the fetus probably do not represent the true picture in vivo of the "basal" state. They regard the high cardiac output and relatively high oxygen capacity of blood and extraction of oxygen in the fetus compared with that of the adult as a means of supplying the fetal tissues with adequate oxygen. Daniel and James [17] also believe that adequate oxygenation of fetal tissues is maintained even with a relatively low arterial $\mathrm{pO}_{2}$.

Marked differences in the patterns of enzyme activity during development have been demonstrated for cardiac and skeletal muscle [32]. There was also a difference in the rates of metabolic development of fetal skeletal and cardiac muscle in these experiments; i.e., the maximum respiration rate occurred at different gestational periods in the two series. This difference is probably related to the fact that the heart begins to beat early in fetal life whereas the skeletal muscle does little work until after birth.

Glucose is reported to be the major or even the sole energy substrate in the mammalian fetus $(15,18)$; certainly the glycolytic pathway develops early in gestation. Villee [37] has previously reported that human fetal heart and diaphragm slices utilize glucose from 7 weeks fetal age to term. In this series fetal heart obtained a maximum of $10 \%$ of the total $\mathrm{CO}_{2}$ from glucose and fetal diaphragm, a maximum of $2 \%$. These values are lower than ours; however, Villee's tissues were incubated in medium at $\mathrm{pH} 6.8$ rather than 7.4 that contained a very high level of pyruvate, $10 \mathrm{~mm}$, as well as glucose. Owing to the difficulty of obtaining human biopsy samples, Villee's series was extremely limited during the last half of gestation, the period in which all our data were obtained, and no data on human infant or adult muscle were available for comparison. However, according to Adam [1] the evidence that carbohydrate is the only energy source of the fetus is indirect. According to Dawes [18] and Dancis [16], none of the evidence excludes the possibility that lipid and protein are oxidized by the fetus. However, proteins are probably used for synthesis rather than for oxidation in the fetus. Villee et al. [38] demonstrated that fetal liver slices do oxidize some radioactive fat to ${ }^{14} \mathrm{CO}_{2}$ although their data were not quantitative. One group studying intact fetuses [33] measured umbilical arterial-venous differences of glucose and fructose in lambs (125-135 days gestaticnal age) and ccncluded that glucose provides cne-half to one-sixth of the metabolic requirements of this preparation. Frcm this divergence of opinion, it is clear that there is need for tetter quantitative information befcre we can conclude that carbchydrate is the major fuel of the fetus.

The data in this paper show that although the overall metabolic rate of the cardiac homogenate is several times greater than that of skeletal muscle in the fetal as well as in the adult series, the percentage of total $\mathrm{CO}_{2}$ arising from carbohydrate in both cardiac (21$35 \%)$ and skeletal muscle $(27-34 \%)$ is relatively low. The percentage of total $\mathrm{CO}_{2}$ arising from carbohydrate in the fetal series is the same in cardiac muscle as in skeletal muscle; in the adult cardiac series, the value is somewhat lower. The interesting conclusion to be drawn from these results is that 65 to $73 \%$ of the total $\mathrm{CO}_{2}$ produced by either type of fetal muscle appears to originate from the oxidation of substrate or substrates other than glucose and glycogen.

The value for the percentage of total $\mathrm{CO}_{2}$ arising from glucose and glycogen in homogenates of adult skeletal muscle $(34 \%)$ agrees with the results previously reported with muscle fiber groups [8]; about $37 \%$ of the oxygen uptake was accounted for by carbohydrate cxidation. These values are somewhat higher than those of Zierler et al. [41], who estimated that the oxidation of glucose by the forearm muscie of man accounts for about $16 \%$ of the total oxygen consumption. Other groups have repcrted values ranging from 0 to 60 for the percentage of oxygen consumption accounted for by glucose oxidation in skeletal muscle [12]. The relative amounts of 
carbohydrate versus lipid utilized by adult cardiac muscle range widely and are influenced by the hormonal and physiologic condition of the animal [10, 27, 34, 39]; the same is probably true of voluntary skeletal muscle but less data are available on this tissue [12].

Although what occurs in homogenates or muscle fiber groups may not reflect what occurs in vivo, the similar results in the fetal and adult series under identical experimental conditions suggest that both fetal and adult skeletal and cardiac muscle are potentially able to obtain a major amount of energy from the oxidation of noncarbohydrate substrates.

Tsoulos et al. [33] concluded that glucose utilization accounts for $50 \%$ or less of the metabolic requirements in fetal lambs. However, Alexander et al. [2] reported that the sheep fetus uses virtually only carbohydrate as its energy source. According to these workers, there may be species differences in substrate utilization by the fetus, and the placenta may be largely responsible for the limitations in the metabolites used by the ovine fetus. Apparently, sheep placenta does not allow appreciable passage of free fatty acid (FFA) from mother to fetus since the FFA concentration in fetal plasma is only $1 / 10$ that in maternal plasma. In the rhesus monkey, however, as well as in human and rabbit placentas [35], there is a rapid transfer across the placenta of FFA from mother to fetus [29], and the FFA concentration in the fetal plasma of rhesus and man is about half that in the maternal plasma [29, 35].

The potential for fatty acid oxidation by the extrahepatic tissues of the adult was well documented even before the use of isotopes. However, until recently, there was a general tendency to minimize its importance, particularly in regard to skeletal muscle. Current work has clearly proved that long chain free fatty acids serve as major energy sources in both adult skeletal and cardiac muscle. Our data suggest that the fetal muscle of some species, both skeletal and cardiac, can also utilize significant amounts of lipid.

In our rhesus monkeys, birth did not cause a significant change in any of the variables investigated. It should be noted that the degree of maturation at birth varies greatly from species to species and that we have severe reservations about making comparisons between human fetal tissues and the fetal tissues of mammals as different as rodents and ungulates. Because the significant features of the growth curve of the rhesus monkey are similar to those of man, Van Wagenen and Catchpole [36] consider this animal an ideal model for the investigation of many phases of human growth and development. Human and rhesus muscle show similar patterns of differentiation during fetal development $[5,19]$.

\section{Summary}

Skeletal muscle homogenates from fetal, neonatal, and adult rhesus monkeys (Macaca mulatta) were prepared with a $\mathrm{CO}_{2}$-cooled homogenizer. At 113 days fetal age, oxygen consumption and $\mathrm{CO}_{2}$ production by homogenates of skeletal muscle were similar to those of adult values; at 155 days fetal age, they were higher. Values for the neonatal and adult series were similar. The percentages of total $\mathrm{CO}_{2}$ and the micromoles $\mathrm{CO}_{2}$ per gram protein per 30 min originating from glucose ${ }^{-14} \mathrm{C}$ plus glycogen were similar in the two fetal, the neonatal, and the adult series. In homogenates of cardiac muscle, oxygen consumption and $\mathrm{CO}_{2}$ production were higher at 113 days fetal age than in adult muscle; by 155 days, values for fetal and adult muscle were similar. The percentage of total $\mathrm{CO}_{2}$ arising from carbohydrate and the micromoles of $\mathrm{CO}_{2}$ produced from the oxidation of carbohydrate were higher in both fetal series than in the adult. No difference was observed when all these parameters were measured in cardiac homogenates from neonates and adults. The $\mathrm{QO}_{2}$ values, $\mathrm{CO}_{2}$ production, and micromoles of $\mathrm{CO}_{2}$ arising from carbohydrate were two- to sevenfold higher in cardiac than in skeletal muscle, the greatest difference occurring in the 113-day fetal series. However, these values in the homogenates of fetal muscle were as high as or higher than those in adult muscle; the values for the neonatal and adult series were similar. Likewise the percentage of $\mathrm{CO}_{2}$ originating from carbohydrate was higher in fetal than in adult cardiac muscle and was similar in both neonatal and adult muscle. In the fetal homogenates from both types of muscle, $65-73 \%$ of the total $\mathrm{CO}_{2}$ produced originated from a noncarbohydrate source or sources. Hence, both skeletal and cardiac homogenates of fetal, neonatal, and adult muscle are potentially capable of obtaining a major part of their energy from the oxidation of a substrate or substrates other than glucose and glycogen.

\section{References and Notes}

1. Adam, P. J. A.: Control of glucose metabolism in the humam fetus and newborn infant. In: R. Levine and R. Luft: $\Lambda d$ vances in Metabolic Disorders, Vol. 5, p. 183. (Academic Press, New York, 1971.)

2. Alexander, D. P., Britton, H. G., Cohen, N. M., and Nixon, D. A. : Foetal metabolism. In: G. E. W. Wolstenholme and M. O'Connor: Foetal Autonomy (Ciba Found. Symp.), p. 95. (Churchill, London, 1969). 
3. Assali, N. S., Rauramo, L., and Peltonen, T.: Measurement of uterine blood flow and uterine metabolism. Amer. J. Obstet. Gynecol., 79: 86 (1960).

4. Beatty, C. H., Basinger, G. M., and Bocek, R. M.: Pentose cycle activity in muscle from fetal, neonatal, and infant rhesus monkeys. Arch. Biochem. Biophys., 117: 275 (1966).

5. Beatty, C. H., Basinger, G. M., and Bocek, R. M.: Differentiation of red and white fibers in muscle from fetal, neonatal, and infant rhesus monkeys. J. Histochem. Cytochem., 15: 93 (1967).

6. Beatty, C. H., Basinger, G. M., and Bocek, R. M.: Oxygen consumption and glycolysis in fetal, neonatal, and infant muscle of the rhesus monkey. Pediatrics, 42: 5 (1968).

7. Beatty, C. H., and Bocek, R. M.: Metabolism of palmitate by fetal, neonatal, and adult muscle of the rhesus monkey. Amer. J. Physiol., 219: 1311 (1970).

8. Beatty, C. H., AND BoceK, R. M.: Interrelation of carbohydrate and palmitate metabolism in skeletal muscle. Amer. J. Physiol., 220: 1928 (1971).

9. Beatty, G. H., Peterson, R. D., Basinger, G. M., and Bocek, R. M.: Major metabolic pathways for carbohydrate metabolism of voluntary skeletal muscle. Amer. J. Physiol., 210: 404 (1966).

10. Bing, R. J.: Cardiac metabolism. Physiol. Rev., 45: 171 (1965).

11. Breuer, E., Barta, E., Zlatoš, L., and Pappová, E.: Developmental changes of myocardial metabolism. Biol. Neonatorum, 12: 54 (1968).

12. Chapler, C. K., and Stainsby, W. N.: Carbohydrate metabolism in contracting dog skeletal muscle in situ. Amer. J. Physiol., 215: 995 (1968).

13. Chen, R. F.: Removal of fatty acids from serum albumin by charcoal treatment. J. Biol. Chem., 242: 173 (1967).

14. Clark, C. M.: Carbohydrate metabolism in the isolated fetal rat heart. Amer. J. Physiol., 220:583 (1971).

15. Cornblate, M., and Schwartz, R.: Disorders of carbohydrate metabolism in infancy. In: Major Problems in Clinical Pediatrics, Vol. III, p. 3. (Saunders, Philadelphia, 1966.)

16. Dancis, J.: Discussion. In: R. M. Wynn: Fetal Homeostasis (Proceedings of the Fourth Conference), Vol. 4, p. 98. (Appleton-Century-Croft, New York, 1969.)

17. Daniel, S. S., and James, L. S.: Lactic acid in the neonatal period in man. N. Y. Acad. Sci., 119: 1142 (1965).

18. DAwES, G. S.: Energy metabolism in the foetus and after birth. In: Foetal and Neonatal Physiology, p. 210. (Yearbook Medical Publishers, Chicago, 1968).

19. Dubowitz, V.: Enzyme histochemistry of skeletal muscle. II. Developing human muscle. J. Neurol. Neurosurg. Psychiat., 28: 519 (1965).

20. Ernster, L., and Nordenbrand, K.: Skeletal muscle mitochondria. In: R. W. Estabrook and M. F. Pullman: Methods in Enzymology, Vol. 10, p. 86. (Academic Press, New York, 1967).

21. Good, N. E., Winget, G. D., Winter, W., Connolly, T. N., IzAWA, S., AND SinGH, R. M. M.: Hydrogen ion buffers for biological research. Biochemistry, 5: 467 (1966).

22. Jolley, R. L., Cheldelin, V. H., and Newburgh, R. W.: Glucose catabolism in fetal and adult heart. J. Biol. Chem., 233: 1289 (1958).
23. KIEssLing, K. H. : Metabolism of growing muscle I. Respiration and oxidative phosphorylation of muscle mitochondria from rats of various ages. Exp. Cell Res. 28: 145 (1962).

24. KIESSLING, K. H.: Metabolism of growing muscle. II. Oxidation of various substrates by mitochondria and homogenates of developing rat muscle. Exp. Cell Res., 31: 8 (1963).

25. Lowry, O. H., Rosebrough, N. J., FArR, A. L., and RaNDALL, R. J.: Protein measurement with the Folin phenol reagent. J. Biol. Chem., 193: 265 (1951).

26. Misrahy, G. A., Beram, A. V., and Hardwrck, D. F.: Fetal and neonatal brain oxygen. Amer. J. Physiol., 203: 160 (1962).

27. Opie, L. H., Evans, J. R., and Shipp, J. C.: Effect of fasting on glucose and palmitate metabolism of perfused rat heart. Amer. J. Physiol., 205: 1203 (1963).

28. Peter, J. B., And Lee, L. D. : Characteristics of skeletal muscle mitochondria isolated by a new improved technique. Biochem. Biophys. Res. Commun., 29: 430 (1967).

29. Portman, O. W., Behrman, R. E., and Soltys, P.: Transfer of free fatty acids across the primate placenta. Amer. $J$. Physiol., 216: 143 (1969).

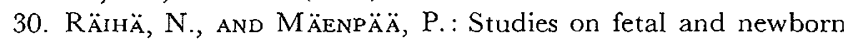
metabolism. Acta Paediat. Scand., Suppl. No. 159: 113 (1965).

31. Rodis, S. L., AND Vahouny, G. V.: Uptake and oxidation of fatty acids by perfused hearts from young and mature rats. Biochim. Biophys. Acta, 208: 153 (1970).

32. Stave, U.: Age-dependent changes of metabolism. I. Studies of enzyme patterns of rabbit organs. Biol. Neonatorum, 6 : 128 (1964).

33. Tsoulos, N. G., Colwill, J. R., Battaglia, F. C., MakowSKI, E. L., AND Meschia, G.: Comparison of glucose, fructose, and $\mathrm{O}_{2}$ uptakes by fetuses of fed and starved ewes. Amer. J. Physiol., 221: 234 (1971).

34. Vahouny, G. V., Katzen, R., and Entenman, C.: Myocardial metabolism. II. Role of nutritional state on palmitate and glucose oxidation by isolated perfused hearts. Biochim. Biophys. Acta, 137: 181 (1967).

35. Van Dyne, C. M., Havel, R. J., and Felts, J. M.: Placental transfer of palmitic acid-1 $-{ }^{14} \mathrm{C}$ in rabbits. Amer. J. Obstet. Gynecol., 84: 1069 (1962).

36. Van Wagenen, G., and Catahpole, H. R.: Physical growth of the rhesus monkey. Amer. J. Physiol. Anthropol., 14: 245 (1956).

37. VilleE, C. A.: The intermediary metabolism of human fetal tissues. In: The Mammalian Fetus: Physiological Aspects of Development (Cold Spring Harbor Symp. Quant. Biol.), Vol. XIX, p. 186. (The Biological Laboratory, Long Island Biological Association, Long Island, New York, 1954).

38. Villee, C. A., Hagerman, D. D., Holmberg, N., Lind, J. AND Villee, D. B.: Effects of anoxia on the metabolism of human fetal tissues. Pediatrics, 22: 953 (1958).

39. Willebrands, A. F., and Tasseron, S. J. A.: Effect of hormones on substrate preference in isolated rat heart. Amer. J. Physiol., 215: 1089 (1968).

40. Wittels, B., and Bressler, R.: Lipid metabolism in the newborn heart. J. Clin. Invest., 44: 1639 (1965).

41. Zrerler, K., Maseri, A., Klassen, G., Rabinowitz, D., AND Burgess, $J$.: Muscle metabolism during exercise in man. Trans. Ass. Amer. Physicians, 81: 266 (1968).

42. Bronwill Scientific, Rochester, N. Y. 
43. AutoAnalyzer, Technicon Instruments Corporation, Tarrytown, N. Y.

44. Tracerlab, ICN, Chemical Radioisotopes Division, Irvine, Calif.

45. Publication no. 605 of the Oregon Regional Primate Research Center, supported in part by Grant no. RR-00163 of the National Institutes of Health. This investigation was supported in part by Public Health Service Research Grant no.
HD-06069 from the National Institute of Child Health and Human Development, by the Muscular Dystrophy Associations of $\Lambda$ merica, Inc., and by the Medical Research Foundation of Oregon.

46. Requests for reprints should be addressed to: Clarissa $\mathrm{H}$. Beatty, Ph.D., Oregon Regional Primate Research Center, 505 N.W. 185th Ave., Beaverton, Ore. 97005 (USA).

47. Accepted for publication June 29, 1972. 